American J. of Engineering and Applied Sciences 2 (1):184-188, 2009

ISSN 1941-7020

(C) 2009 Science Publications

\title{
Experimental Investigation on Geomechanical Properties of Tropical Organic Soils and Peat
}

\author{
Bujang B.K. Huat, Afshin Asadi and Sina Kazemian \\ Department of Civil Engineering, \\ University Putra Malaysia, Serdang, Selangor, Malaysia
}

\begin{abstract}
Problem statement: Organic soils and peat were believed to be geotechnically problematic due to their very high compressibility, very low shear strength and difficult accessibility. Although conventional soil mechanics theory could be applied to the soils, it was found that important anomalies existed which required special considerations. Correlations between geomechanical parameters for the soils were known to be important for geotechnical engineers to be able to obtain suitable design parameters, as well as to find suitable construction techniques on these soft materials. Approach: To evaluate the geomechanical characteristics of the soils, field and laboratory investigations were carried out according to the organic contents. To achieve such purpose, the soils samples having different organic contents from several locations in Malaysia were collected to determine the correlations of various geomechanical properties of the soils. The classifying tests were determined based on the test procedures according to the British Standard Institution. The compressibility behavior of the soils was determined by Rowe cell consolidation test. Results: The test results indicated that the natural water contents, organic contents, liquid limits, specific gravities and bulk densities ranged from $150-700 \%$, 50-95\%, 180-500\%, 1.05-1.9 and 0.8-1.2 $\mathrm{Mgm}^{-3}$, respectively. The compression indexes of the soils were higher than Hobbs and Skempton's approximations. Conclusion/Recommendations: The soils properties were highly dependent on the organic contents. With an increase in organic content, the natural water content, liquid limit, compression index and void ratio increased and the specific gravity and bulk density decreased. Furthermore, the hemic and sapric peat had lower shear strength than the fibrous peat. The first-of-its-kind study was the first step on the road to persuade researchers to improve these problematic soils.
\end{abstract}

Key words: Peat soil, organic soil, geomechanical properties, humification

\section{INTRODUCTION}

Peat is a mixture of fragmented organic material formed in wetlands under appropriate climatic and topographic conditions and it is derived from vegetation that has been chemically changed and fossilized ${ }^{[1]}$. Peat is partially or totally decomposed remains of dead plants which have accumulated under water for tens to thousands of year. Decomposition or humification involves the loss of organic matter either in gas or in solution, the disappearance of physical structure and the change in chemical state.

Peat is generally found in thick layers in limited areas, has low shear strength and high compressive deformation which often results in difficulties when construction work is undertaken on the deposit. Peat represents the extreme form of soft soil. It is an organic soil which consists more than $75 \%$ of organic matters ${ }^{[2]}$.
However, the cutoff value of the percentage of organic matter necessary to classify a superficial deposit or soil as peat varies throughout the world, usually depending on the purpose of classification. This cutoff value also serves to differentiate peat from superficial deposits or soils with lesser amounts of organic content. The terms peat and organic soils, used for describing soils with an organic content, were once synonymous but term organic soils is presently used for superficial deposits or soils that contain organic matter $^{[2]}$.

Development of peat land: These soils are found in many countries throughout the world. In the US, peat is found in 42 states, with a total acreage of 30 million hectares. Canada and Russia are two other countries with a large area of peat, 170 and 150 million hectares, respectively ${ }^{[3]}$. For cases of tropical peat, or tropical

Corresponding Author: Bujang B.K. Huat, Department of Civil Engineering, University Putra Malaysia, 43400 Serdang, Selangor, Malaysia 
peat lands, the total world coverage is about 30 million hectares, two thirds of which are in Southeast Asia. Malaysia has some 3 million hectares, about $8 \%$ of the country's land area covered with tropical peat. In Indonesia peat covers about 26 million hectares of the land area, with almost half of the peat land total in Kalimantan.

Classification of peat and organic soils: The soils with organic content of greater than $20 \%$ are generally termed organic soils. Peat is an organic soil which consists more than $75 \%$ of organic matters. The precise classification of peat however varies between soil science and engineering, as well as between countries. The geomechanical engineering definition is essentially based on geotechnical properties of the soil.

However Hobbs $^{[4]}$ and Edil ${ }^{[5]}$, suggest the important following characteristics should be included in a full description of a peat: Color, degree of humification (fibric, hemic, sapric), water content, organic content, Atterberg's consistency and fiber content.

The content of peat soil differs from location to location due to the factor such as the origin fiber, temperature and humidity.

These soils are geomechnically problematic due to their high compressibility and low shear strength. Hence, suitable geomechnical design parameters and construction techniques needed for this type of ground condition.

This study presented correlations of engineering properties and compressibility behavior of various types of tropical peat soil from several locations in Malaysia.

\section{MATERIALS AND METHODS}

The main objective of this research was to find out the effect of organic content on geomechnical parameters. Geomechnical properties of peat soil used in the classification system of peat namely: The water content, organic content, specific gravity, fiber content, degree of humification, Atterberg limits and shear strength parameters were determined based on test procedures according to the British Standard Institution $^{[6]}$. Apart from the classifying tests, compressibility behavior of the peat soil was determined by Rowe cell consolidation test.

Peat soil samples collected from several locations in Malaysia, namely Johore, Perak, Sarawak and Selangor. These soils represented tropical organic and peat soils with organic content ranging from 50$95 \%$.

\section{RESULTS}

Correlations of index properties:

Water content-organic content: Figure 1 shows plot of organic content with natural water content of tropical organic soils.

The natural water contents of these soils were found to the range from $150-700 \%$, with organic content in the range of 50-95\%. Empirical relationship between organic content with natural water content of tropical organic soils could be written as:

$$
\mathrm{OC}(\%)=0.0592 \mathrm{~m}(\%)+54.34
$$

Where:

$\mathrm{m}=$ Water content

$\mathrm{OC}=$ Organic content

Organic content-liquid limit: Figure 2 shows the graph of organic content versus the liquid limit.

Empirical relationship between organic content and liquid limit was found as:

$$
\mathrm{OC}(\%)=0.1747 \mathrm{LL}(\%)+20.377
$$

Where:

$\mathrm{LL}=$ Liquid limit

$\mathrm{OC}=$ Organic content

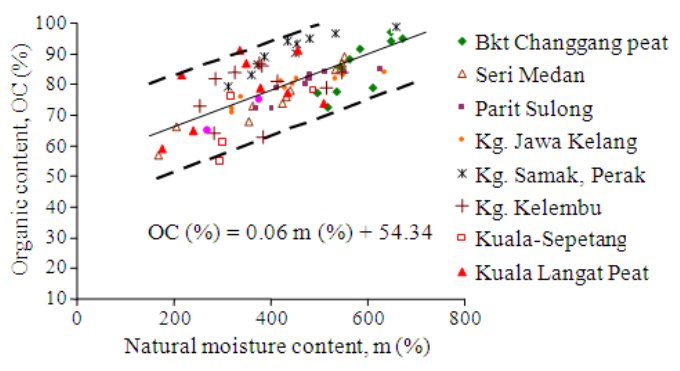

Fig. 1: Water content-organic content

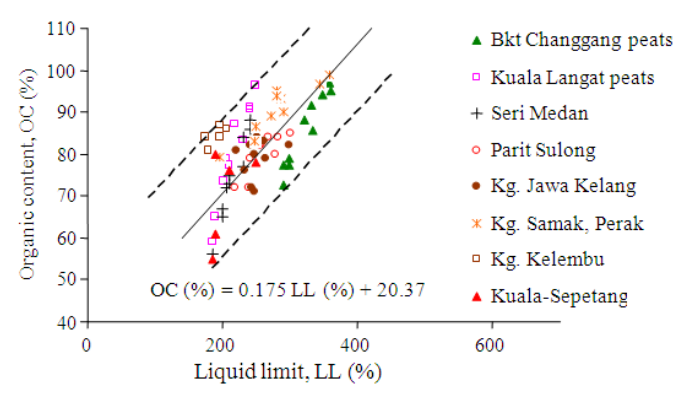

Fig. 2: Organic content-liquid limit 


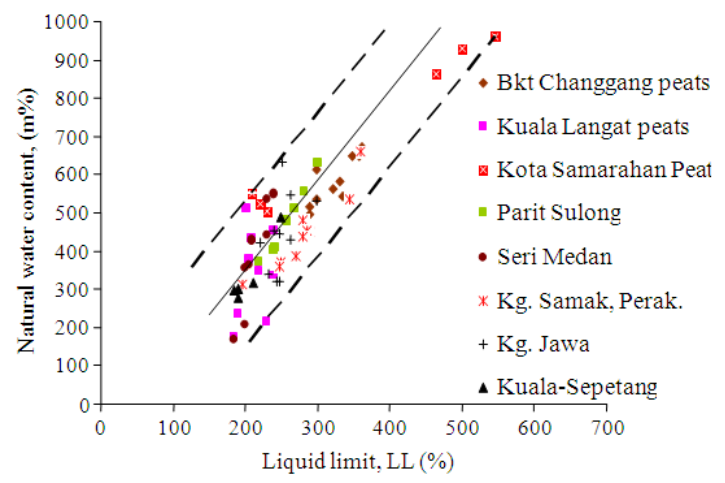

Fig. 3: Natural water content-liquid limit

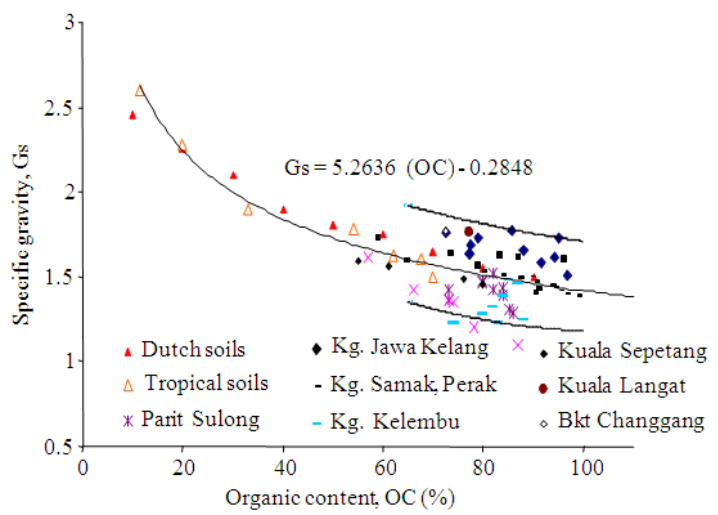

Fig. 4: Specific gravity-organic content

Based on this study, the range of liquid limit was from $180-500 \%$ for the Malaysian peat soils.

Water content-liquid limit: Figure 3 shows a plot of water content versus the liquid limit.

Specific gravity-organic content: Figure 4 showed a graph of specific gravity with organic content, for peat soils.

The average specific gravity of organic soil particles could be calculated from:

$$
\text { Gs }=5.2636 \times(\mathrm{OC})^{-0.2848}
$$

Where:

Gs = Specific gravity

$\mathrm{OC}=$ Organic content

Specific gravity of the peat was in the range of 1.05-1.9, in about the same range to that of Den $\operatorname{Haan}^{[8]}$ observations.

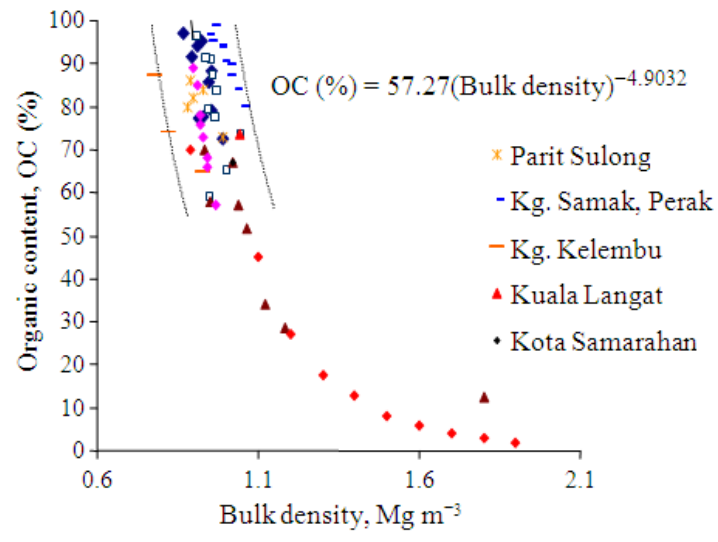

Fig. 5: Bulk density-organic content

Based on the experimental data obtained in the laboratory, our observations approximately agreed with correlation proposed by Den Haan ${ }^{[8]}$, which is:

$$
\mathrm{G}_{\mathrm{s}}=1 /(0.362 \times \mathrm{OC}+0.371) \mathrm{z}
$$

Bulk density-organic content: Figure 5 shows a graph of bulk density and organic content of the tropical peat and organic soils of this study.

The following relationship was derived from tropical peat soils:

$$
\mathrm{OC}=57.266 \times \gamma_{\mathrm{b}}^{-4.9032}
$$

Where:

$\mathrm{OC}=$ Organic content

$\gamma_{\mathrm{b}}=$ Bulk density

The bulk density of organic soil was in the range of 0.8-1.2 $\mathrm{Mg} \mathrm{m}^{-3}$ compared with the bulk density of mineral soils which is in the range of $1.8-2.0 \mathrm{Mg} \mathrm{m}^{-3}$.

\section{Compressibility:}

Correlations of compressibility properties:

Compression index-liquid limit: The plot of found compression index $\left(\mathrm{C}_{\mathrm{c}}\right)$ versus the liquid limit of the organic soils (Fig. 6) shows that $\left(\mathrm{C}_{\mathrm{c}}\right)$, increased with increase in liquid limit of the soils.

Void ratio-liquid limit: Figure 7 shows a plot of the initial voids ratio versus liquid limit values obtained for tropical peats from Malaysia together with those normally consolidated peat found $\mathrm{by}^{[2]}$. The general trend was the void ratio that increased with increase in liquid limit. 


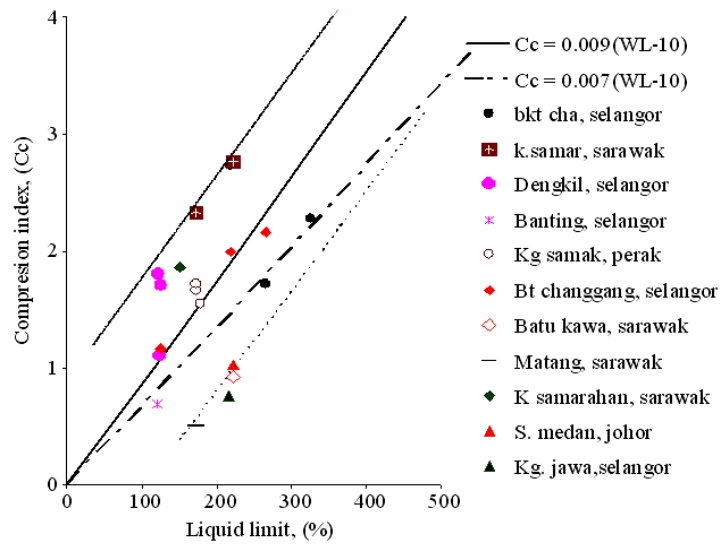

Fig. 6: Compression index-liquid limit

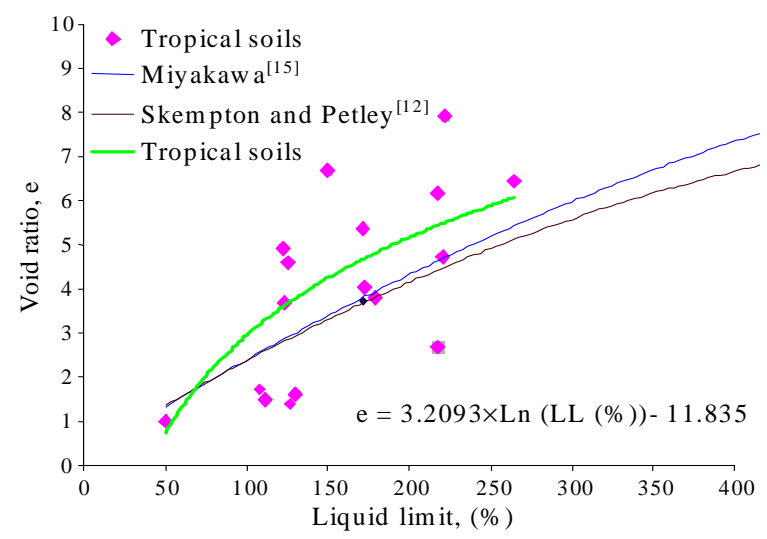

Fig. 7: Void ratio-liquid limit

Its relationship is:

$$
\mathrm{e}=3.2093 \times \operatorname{Ln}(\operatorname{LL}(\%))-11.835
$$

Where:

$$
\begin{aligned}
& \mathrm{e}=\text { Void ratio } \\
& \mathrm{LL}=\text { Liquid limit }
\end{aligned}
$$

Compression ratio-liquid limit: The values of $\left(\mathrm{C}_{\mathrm{c}} / 1+\mathrm{e}_{0}\right)$ determined from the laboratory test on tropical organic soil samples from Malaysia are shown in Fig. 8.

\section{Shear strength:}

Vane shear strength-moisture content: The plot of moisture content against vane shear strength was shown in Fig. 9.

At the same moisture content, the high fibrous peat $\left(\mathrm{H}_{1}-\mathrm{H}_{3}\right)$ gave higher strength compared with the medium and low fibrous peat $\left(\mathrm{H}_{4}-\mathrm{H}_{10}\right)$.

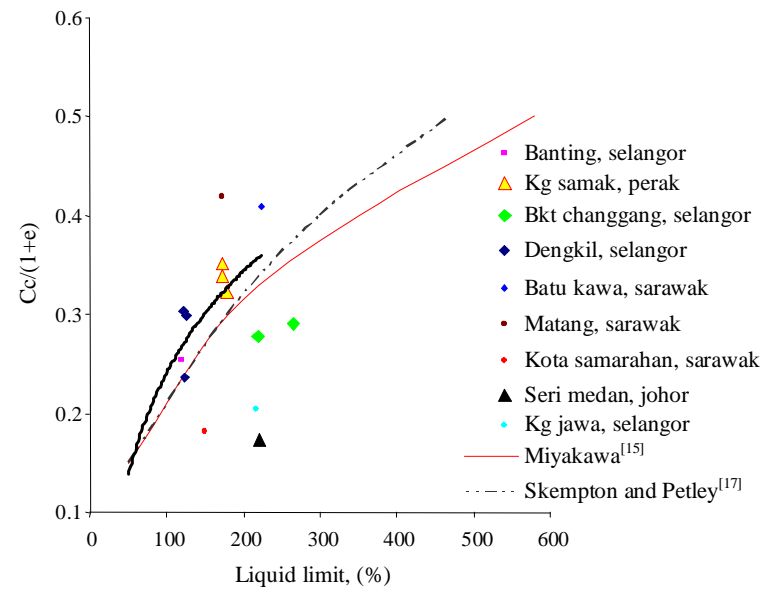

Fig. 8: Compression ratio-liquid limit

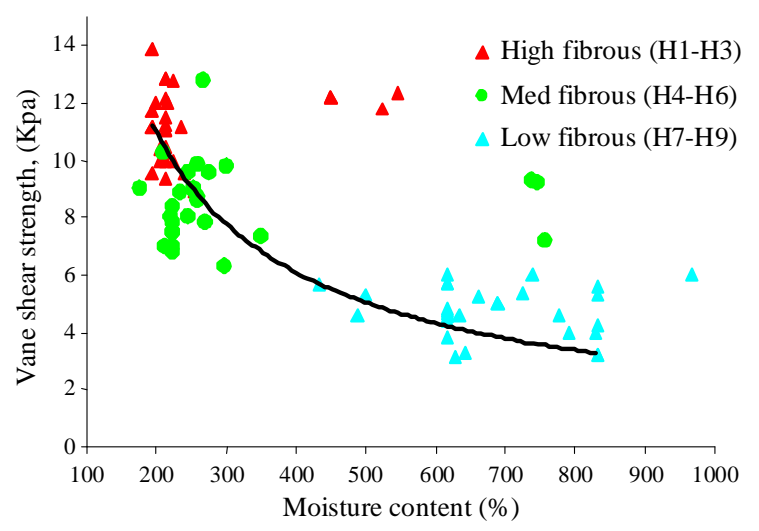

Fig. 9: Vane shear strength-moisture content

\section{DISCUSSION}

Peat and water: For organic soil, the water is held in the organic matters and cells of the plant remain. Organic soils had very high natural water content, which could be in excess of $700 \%$, compared with mineral soils (sand, silt and clay), whose values in the field may range between 3-70\%, but with values of greater than $100 \%$ are sometimes found in soft soils below ground water table.

These observations agreed with what have been carried out by McBrierty ${ }^{7]}$, but the maximum water content, found in tropical organic soils with high organic content is less than Irish peat ${ }^{[7]}$.

Organic contents and peat index parameters relationships: The natural water contents and liquid limits were found to increase with increase in organic content. The specific gravity of peat decreased, with increase in organic content. According to the test results, the bulk density increased with decrease in 
organic content. This was due to the lower specific gravity of the particles and the higher water holding capacity in peat compared to mineral soils. The results revealed that organic content played a key role in the soils properties.

Deformation characteristics of peat: The empirical relationship between the compression index and liquid limit suggested by ${ }^{[2]}$ for organic soils $\left(\mathrm{C}_{\mathrm{c}}=0.009\left(\mathrm{~L}_{\mathrm{L}}-10\right)\right)$ gave a reasonable approximation of these parameters. Hobbs ${ }^{[4]}$ estimated the compression index of fen peat was about $0.007\left(\mathrm{~L}_{\mathrm{L}}-10\right)$, which gives slightly lower value of $\left(\mathrm{C}_{\mathrm{c}}\right)$.

Compression index of tropical peat samples tested (Fig. 6) however, were apparently little higher than the above two relationships.

Hobbs $^{[4]}$ found the ratio of $\left(\mathrm{C}_{\mathrm{c}} / 1+\mathrm{e}_{0}\right)$ was small. Our observation is in agreement with Hobbs ${ }^{[4]}$ study. The trend is similar to other researches but slightly higher, which is likely due to higher in situ void ratio $\left(e_{0}\right)$. The value of $\left(e_{0}\right)$ depends on the in situ vertical stress; hence, $\left(\mathrm{e}_{0}\right)$ should be that appropriate to the very low effective stress conditions.

Correlations between shear strength properties: Figure 9 showed a decreasing behavior of shear strength with increasing water content. Determination of shear strength parameters for organic soils, as with other soils, is important and somehow a difficult job in geomechnical engineering. For organic soils, several methods have been used to determine the undrained shear strength namely; laboratory Swedish fall-cone test, triaxial test, shear box test and vane shear test. Presence of fibers and their varying interaction within the shearing mode imposed by the particular testing procedure however creates difficulties in assessing the true operating strength value. The fibric peat $\left(\mathrm{H}_{1}-\mathrm{H}_{3}\right)$ had higher shear strength than hemic $\left(\mathrm{H}_{4}-\mathrm{H}_{6}\right)$ and sapric $\left(\mathrm{H}_{7}-\mathrm{H}_{10}\right)$ peat.

\section{CONCLUSION}

- The natural water content was found to increase with increase in organic content. The natural water contents of organic soils were found to range from $150-700 \%$, with organic content in the range of 50$95 \%$

- The liquid limit of the organic soils increased with increase in organic content. The range of liquid limit was between $180-500 \%$ for the Malaysian peat soils

- The liquid limit of tropical peat and organic soils of this study was found to increase with increase in water content

- The specific gravity of peat decreased, with increase in organic content and Specific gravity of the peat was the range of 1.05-1.9
- The bulk density increased with decrease in organic content. The bulk density of organic soils was in the range of $0.8-1.2 \mathrm{Mg} \mathrm{m}^{-3}$

- The compression index $\left(\mathrm{C}_{\mathrm{c}}\right)$, increased with increase in liquid limit of the soils. The void ratio increased with increase in liquid limit

- Despite the large variations, which occurred within organic and peat soils, the variation in the ratio of $\left(\mathrm{C}_{\mathrm{c}} / 1+\mathrm{e}_{0}\right)$ was relatively small

- In general, fibric peat $\left(\mathrm{H}_{1}-\mathrm{H}_{3}\right)$ had higher shear strength than hemic $\left(\mathrm{H}_{4}-\mathrm{H}_{6}\right)$ and sapric $\left(\mathrm{H}_{7}-\mathrm{H}_{10}\right)$ peat

\section{ACKNOWLEDGEMENT}

Sincere appreciation is attributed to the Ministry of Science, Technology and Innovation Malaysia for providing a fund (cement column stabilization of peat soils, ref. 5450411) to make the research on the peat soil possible.

\section{REFERENCES}

1. Mesri, G. and M. Ajlouni, 2007. Engineering properties of fibrous peats. J. Geotech. Geoenviron. Eng., 133. DOI: 10.1061/(ASCE)10900241(2007)133:7(850)

2. Huat, B.B.K., 2004. Organic and Peat Soils Engineering. 1st Edn., University Putra Malaysia Press, Serdang, Malaysia, pp: 31-66.

3. Hartlen, J. and J. Wolski, 1996. Embankments on Organic Soils. 1st Edn., Elsevier, USA, ISBN: 10: 0-444-88273-1, pp: 456.

4. Hobbs, N.B., 1986. Morphology and the properties and behavior of some British and foreign peats. Q. J. Eng. Geol., 19: 7-80.

DOI: 10.1144/GSL.QJEG.1986.019.01.02

5. Edil, T.B. and X. Wang, Shear strength and $\mathrm{K}_{0}$ of peats and organic soils. Geotechn. High Water Content Mater., 1374: 209-225. http://direct.bl.uk/bld/PlaceOrder.do?UIN=076010 420\&ETOC $=$ RN\&from $=$ searchengine

6. B.S. 1377-3, 1990. Methods of test for Soils for civil engineering purposes.

http://www.standardsdirect.org/standards/standards 4/StandardsCatalogue24_view_462.html

7. McBrierty, V.J., G.E. Wardell, C.M. Keely and E.P. O'Neill, 1996. The characterization of water in peat. Soil Sci. Soc. Am. J., 60: 991-1000. http://soil.scijournals.org/cgi/search?andorexactfull text=and\&resourcetype $=1 \&$ disp_type $=\&$ sortspec $=r$ elevance \&author $1=\&$ fulltext $=\&$ pubdate_year $=199$ $6 \&$ volume $=60 \&$ firstpage $=991$

8. Den Haan, E.J., 1996. A compression model for non-brittle soft clays and peat. Int. J. Rock Mech. Min. Sci. Geomech., 33: 355-365. DOI: 10.1016/S0148-9062(97)87399-8 